\title{
Pengaruh Pendidikan Kependudukan dan Lingkungan Hidup terhadap Perilaku Peduli Lingkungan
}

\author{
BAMBANG SYAEFUL HADI DAN MUHSINATUN SIASAH MASRURI \\ Fakultas Ilmu Sosial, Universitas Negeri Yogyakarta \\ bb_saifulhadi@lycos.com
}

\begin{abstract}
Abstrak
Penelitian ini bertujuan untuk mengetahui: (1) peran sikap dan norma subjektif mahasiswa dalam membentuk perilaku peduli lingkungan, dan (2) perbedaan perilaku peduli lingkungan antara mahasiswa yang memperoleh matakuliah PKLH Plus, mahasiswa yang memperoleh matakuliah PKLH, dan mahasiswa yang tidak memperoleh mata kuliah PKLH. Populasi penelitian adalah mahasiswa FISE UNY tahun 2009, berjumlah 2507 orang. Jumlah sampel sebanyak 338 mahasiswa, yang diambil dengan proportional dan systematic random sampling. Pengumpulan data dilakukan dengan angket. Model perilaku yang digunakan adalah Extended Fishbein Model. Teknik analisis data yang digunakan adalah analisis deskriptif dan One Way Anova, dengan taraf signifikansi 0,05. Hasil penelitian menunjukkan bahwa pada umumnya mahasiswa mempunyai perilaku kurang peduli terhadap lingkungan. Dari ketiga kelompok mahasiswa tersebut, mahasiswa PKLH Plus dan mahasiswa PKLH biasa mempunyai perilaku kurang peduli, kelompok mahasiswa non PKLH memiliki perilaku tidak peduli pada lingkungan. Perilaku kurang peduli terhadap lingkungan lebih disebabkan kurangnya pengetahuan terhadap dampak dari perilaku tersebut terhadap lingkungan. Atribut sikap mempunyai bobot lebih besar daripada norma subjektif. Proporsi bobot pada masing-masing kelompok mahasiswa adalah 74,25\% dan 25,75\%, 70\% dan 30\%, dan 69\% dan 31\%. Hasil Anava menunjukkan nilai $\mathrm{F}=6,948$ dengan $\mathrm{p}=0,001$, artinya terdapat perbedaan perilaku peduli lingku ngan yang signifikan antara ketiga kelompok mahasiswa yang memperoleh porsi pendidikan lingkungan yang berbeda.
\end{abstract}

Kata kunci: PKLH, keyakinan, norma, perilaku peduli lingkungan

\begin{abstract}
This research aims to investigate: (1) the role of attitudes and students' subjective norms in building the students 'environmental awareness behavior and (2) the difference between environmental awareness behavior of the students who attended PKLH-plus course, attended PKLH course, and the students who did not attend PKLH course. The population includes 2,507 students of FISE UNY at 2009. The samples are 338 students taken using the proportional sampling and systematic random sampling technique. The data were collected using a questionnaire. The behavioral model utilized in this research is the Extended Fishbein Model. The data analysis techniques employed in this research were descriptive analysis and One Way Anova, with the significance level of 0.05. The results show that the students generally do not care much about the environment. Among those three groups of students, students who took PKLH-plus course and students who joined PKLH course perform less care to the environment. Meanwhile, non-PKLH student groups have no care of the environment.This is caused by their lack of knowledge on the impact of such behavior on the environment. The attribute of the attitude has a greater weight than the subjective norm. The proportion of the weight of each group is 74,25\% and 25,75\%; 70\% and 30\%; and 69\% and 31\%. The result of Anova shows the value of $F=6.948$ with the significance level $p=$ of 0.001 which means that there is a significant difference of the environmental awareness behavior among the three groups of students who obtain a different portion of environmental education.
\end{abstract}

Keywords: PKLH, belief, norms, environmental awareness behavior 


\section{PENDAHULUAN}

Dewasa ini, kesadaran lingkungan masyarakat dalam keadaan yang sangat memprihatinkan. Perilaku manusia yang mencerminkan ketidaktahuan, ketidakpedulian, keserakahan dan arogansi kekuasaan manusia telah menjadikan lingkungan sebagai sasaran kedzaliman tindakan mereka. Keserakahan manusia telah mendorong mereka menganiaya lingkungan dengan mengeksploitasi alam secara berlebihan apalagi bila tindakan tersebut berupa pencurian, seperti pencurian kayu. Konversi hutan menjadi perkebunan kelapa sawit, khususnya di Sumatera dan Kalimantan yang mencapai 400.000 hektar/tahun, sehingga saat ini mencapai luasan 8,4 juta hektar (MPBI, 2010) telah menjadi sumber bencana banjir dan dalam jangka panjang akan menjadi penyebab kekeringan,. Banjir merupakan fenomena yang terjadi akibat kesalahan pandang dan kesalahan perilaku manusia dalam mengelola lingkungan (Aris Marfai, 2005:1718).

Chiras (1985:454-460) menggolongkan faktor perusak lingkungan yang berasal dari manusia menjadi empat, yakni: perilaku manusia bermentalitas frontier, kesulitan teknologis (tecnological fix), pandangan-pandangan pribadi yang bersifat subjektif, dan masyarakat bersinergi rendah. Mentalitas frontier, ditunjukkan oleh sifat-sifat berikut: skin-encapsulated ego, cavalier attitude, derived self, reaffirmation throught materialism, biological imperealism, Judeo Christian teaching. Kesulitan teknologis yang dimaksud adalah kesulitan atau kebuntuan dalam memperoleh/menggunakan bahan atau teknik tertentu yang ramah lingkungan. Pandanganpandangan pribadi, yang meliputi : apatis, mementingkan diri sendiri, perasaan kurang berarti, nilai ruang dan waktu yang terbatas, masyarakat bersinergi rendah

Untuk meminimalisasi kemungkinan berkembangnya elemen-elemen masyarakat yang menjadi agen perusak lingkungan, maka dipandang perlu untuk memberikan pendidikan lingkungan kepada masyarakat, baik melalui jalur formal maupun non-formal. Di sekolah-sekolah sampai perguruan tinggi perlu diajarkan pendidikan lingkungan. Pendidikan lingkungan yang ada di sekolah selama ini baru diselipkan pada materi-materi tertentu yang mungkin berhubungan dengan lingkungan. Di perguruan tinggi, pendidikan lingkungan pernah mendapat perhatian yang cukup memadai, termasuk di dalamnya UNY. UNY sejak masih bernama IKIP Yogyakarta, memasukkan pendidikan lingkungan menjadi mata kuliah wajib universiter, yakni dalam mata kuliah Pendidikan Kependudukan dan Lingkungan Hidup (PKLH). Dengan adanya pendidikan lingkungan bagi mahasiswa ini diharapkan kelak mereka menjadi sarjana yang memahami posisi dirinya sebagai makhluk penghuni bumi dalam perpektif ekologis yang terwujud dalam bentuk cinta lingkungan dan berjuang untuk melestarikan fungsi lingkungan.

Pendidikan lingkungan disadari oleh berbagai pihak merupakan hal yang sangat penting karena perilaku dan tindakan manusia terhadap lingkungan sangat berpengaruh terhadap masa depan manusia dan lingkungannya. Berbagai musibah lingkungan di berbagai belahan dunia, termasuk di Indonesia diantara penyebabnya adalah ulah manusia. Oleh karena itu di berbagai perguruan tinggi, khususnya di lingkungan Lembaga Pendidikan Tenaga Kependidikan (LPTK) yang bertugas membina calon-calon guru, pendidikan lingkungan yang berlabel PKLH diwajibkan sebagai mata kuliah yang masuk dalam kelompok Mata Kuliah Pengembangan Kepribadian (MPK) harus ditempuh oleh seluruh mahasiswa.

Mengingat arti penting pendidikan lingkungan bagi mahasiswa, maka dalam dinamika perkembangan kurikulum (Kurikulum 1986, Kurikulum 1998, Kurikulum 2000, dan Kurikulum 2000 Suplemen) PKLH selalu bertahan sebagai MPK yang bersifat universiter. Anehnya ketika persoalan lingkungan sekitar, semakin memprihatinkan bahkan telah mengancam masa depan manusia, justru lahir kebijakan kurikulum di UNY yang menempatkan mata kuliah PKLH bukan sebagai mata kuliah wajib yang bersifat universiter, meskipun 
masih tertera dalam kelompok MPK.

Keputusan UNY yang menyebabkan PKLH tereliminasi dari kurikulum berbagai program studi adalah pembuatan ramburambu penyediaan jumlah mata kuliah MPK yang melebihi ketentuan SK Mendiknas RI nomor 232/U/2000 dan 045/U/2002. Rambu-rambu tersebut berisi ketentuan klasifikasi dan jumlah SKS mata kuliah, masing-masing klasifikasi adalah MPK 10\%, MKK 20\%, MKB 50\%, MPB 10\%, dan MBB 10\%. Umumnya alasan berbagai program studi yang tidak mengambil PKLH sebagai bagian dari MPK karena PKLH dapat diintegrasikan ke mata kuliah lain pada topik-topik tertentu. Me nurut hasil penelitian Bambang Syaeful Hadi (2008:44) di lingkungan FISE UNY, sebanyak 96\% dosen pernah mengintegrasikan, tetapi hanya $10 \%$ dosen yang melakukannya secara terencana, bahkan yang memprihatinkan $64 \%$ dosen hanya melakukannya secara improvisasi saja. Kondisi ini sangat meprihatinkan, mengingat bahwa mata kuliah tersebut memiliki peran strategis dalam upaya membentuk perilaku peduli lingkungan.

Implementasi Kurikulum 2002 di UNY memberikan keleluasaan kepada jurusan/ program studi untuk memilih mata kuliahmata kuliah yang termasuk kelompok Mata Kuliah Pengembangan Kepribadian (MPK). Pemberian keleluasaan untuk memilih jenis mata kuliah kelompok MPK berdampak pada perbedaan komposisi jenis mata kuliah MPK yang diambil oleh jurusan/program studi di setiap fakultas. Salah satu mata kuliah yang membuat komposisi MPK masing-masing program studi menjadi berbeda adalah Mata Kuliah Pendidikan Kependudukan dan Lingkungan Hidup (PKLH). Ada jurusan yang mengambil mata kuliah PKLH sebagai bagian dari MPK dan ada jurusan yang tidak memasangnya.

Lahirnya kurikulum 2002 berimplikasi pada variasi program studi dalam penyeleng garan pendidikan lingkungan di FISE. Dalam konteks penyelenggaraan pendidikan lingkungan ini variasi program studi dapat dikelompokkan menjadi 3, yakni: (a) program studi yang memasang PKLH sebagai MPK; (b) program studi yang tidak memasang
PKLH dalam MPK kurikulumnya; dan (c) program studi yang memasang PKLH dalam MPK-nya sekaligus memperoleh pendidikan lingkungan lainnya. Adanya perbedaan tersebut secara teoretik akan berpengaruh terhadap pembentukan perilaku positif mahasiswa terhadap lingkungan. Hanya saja dalam praktiknya evaluasi pembelajaran PKLH sering hanya untuk mengetahui aspek kognitif, sementara ranah afektif dan psikomotor belum diukur secara memadai. Berbagai macam model pengukuran sikap belum diapli kasikan oleh dosen pengampu PKLH untuk mengukur keberhasilan pembelajaran pendidikan lingkungan, termasuk Model Fishbein yang sangat populer pun belum digunakan.

Model Fishbein dapat digunakan untuk berbagai aspek, termasuk untuk mengukur kepedulian lingkungan. Untuk keperluan tersebut, maka dilakukan modifikasi atribut.

Perilaku peduli lingkungan merupakan ranah psikomotor. Berdasarkan teori perkembangan moral Kohlberg (Reimer, Paolitto dan Hersh, 1983:94-103), perilaku di pengaruhi oleh moral cognitif. Moral kognitif merupakan seperangkat pengetahuan tentang nilai-nilai yang menuntun orang untuk berperilaku dan bertindak (moral action). Kaitannya dengan pendidikan lingkungan di FISE UNY adalah bahwa pendidikan lingkungan merupakan upaya membekali mahasiswa dengan seperangkat pengetahuan dan nilai-nilai lingkungan, sehingga mahasiswa diharapkan dapat berperilaku peduli terhadap lingkungan. Sementara di lingkungan fakultas yang sama, banyak terdapat mahasiswa dari beberapa jurusan yang tidak memperoleh pendidikan lingkungan, maka berdasarkan teori perkembangan moral tersebut mahasiswa yang memperoleh pendidikan lingkungan dengan mahasiswa yang tidak memperoleh pendidikan lingkungan akan mempunyai pengetahuan dan nilai-nilai lingkungan serta perilaku yang berbeda-beda. Seperangkat pengetahuan dan nilai-nilai lingkungan yang dimiliki mahasiswa ini ter ekspresi dalam bentuk sikap dan perilaku yang berlandaskan pada moral lingkungan.

Hasil penelitian Bambang Syaeful Hadi (2007:40) menunjukkan bahwa 66,67\% 
mahasiswa FISE UNY tidak pernah melakukan tindakan untuk menjaga kebersihan lingkungan kampus, fakta ini menunjukkan bahwa kesadaran mahasiswa untuk menjaga kebersihan lingkungan kampus masih sangat rendah. Bahkan di kalangan dosen (sebagian di antaranya berasal dari jurusan yang menghendaki pembelajaran PKLH secara terintegrasi), 54\% dosen tidak pernah menganjurkan mahasiswa untuk memperhatikan kebersihan kelas. Hal ini menunjukkan masih sangat rendahnya kepedulian civitas akademika terhadap kebersihan lingkungan kampus.

Adanya perbedaan pola pendidikan lingkungan di berbagai jurusan di FISE UNY berimplikasi pada ketidaksamaan dalam upaya memberikan seperangkat pengetahuan, yang menurut Fishbein dan Ajzen (1975:340-341) seperangkat pengetahuan(cognitive)inidapatmembentuk keyakinan (bilief) yang selanjutnya bersama dengan pengaruh pendapat orang lain (subjective norm) sebagai referensi akan membentuk perilaku. PKLH merupakan cara membekali seperangkat pengetahuan lingkungan, sehingga berdasarkan pengetahuan yang dimiliki tersebut mahasiswa dapat bersikap dan berperilaku yang peduli terhadap lingkungan. Model Fishbein diperluas (Extended Fishbein Model) memberi ruang untuk mengetahui peran orang di sekitar mahasiswa yang berperan dalam membentuk perilaku, dalam hal ini dosen dan teman. Model ini memungkinkan untuk mengetahui faktor mana yang lebih berperan terhadap pembentukan perilaku peduli lingkungan mahasiswa yang memperoleh pendidikan lingkungan yang beragam porsinya. Porsi dalam pengertian ada kelompok mahasiswa dari program studi yang memperoleh pendidikan lingkungan dalam jumlah SKS yang banyak (PKLH Plus), ada yang hanya 2 SKS dan ada yang sama sekali tidak memperoleh. Berdasarkan fakta-fakta tersebut peneliti tertarik untuk mengungkapkan pengaruh pendidikan lingkungan dalam membentuk perilaku peduli lingkungan mahasiswa tersebut.

Dari latar belakang masalah yang telah dikemukakan di atas dapat diidentifikasi sejumlah permasalahan yang terkait dengan pendidikan lingkungan di FISE UNY, yakni: (1) Kesadaran mahasiswa dan dosen untuk membersihkan lingkungan kelas/kampus masih rendah. Ini menjadi indikasi rendahnya perilaku positif mahasiswa terhadap lingkungan; (2) Evaluasi pembelajaran lingkungan masih berorientasi pada aspek kognitif, sementara aspek lainnya (afektif dan psikomotor) masih terabaikan; (3) Banyak mahasiswa di berbagai program studi di lingkungan FISE UNY yang tidak memperoleh pendidikan lingkungan yang terprogram; (4) Belum pernah ada pengukuran tingkat keberhasilan pendidikan lingkungan secara komprehensif dalam pembentukan perilaku positif terhadap lingkungan di FISE UNY; (5) Belum ada informasi yang menggambarkan bagaimana perilaku peduli lingkungan mahasiswa FISE UNY; (6) Belum diketahui diantara faktor sikap dan norma subjektif mana yang memiliki peran lebih besar dalam pembentukan perilaku peduli lingkungan mahasisawa FISE UNY; (7) Terdapat kesenjangan dalam kuantitas pendidikan lingkungan di berbagai program studi di lingkungan FISE UNY; (8) Wahana pendidikan lingkungan di kampus UNY semakin menyempit dengan tereliminasinya PKLH dari MPK dalam struktur kurikulum masingmasing program studi; (9) Belum diketahui perbedaan perilaku peduli lingkungan antara mahasiswa yang memperoleh matakuliah PKLH Plus, mahasiswa yang memperoleh matakuliah PKLH biasa, dan mahasiswa yang tidak memperoleh mata kuliah PKLH.

Berdasarkan uraian permasalahan di atas peneliti membatasi diri hanya pada masalah yang penulis anggap urgen untuk diperoleh soulsinya, yakni masalah: (1) bagaimana peran sikap dan norma subjektif dalam membentuk perilaku peduli lingkungan pada mahasiswa yang memperoleh porsi pendidikan lingkungan berbeda? (2) apakah terdapat perbedaan perilaku peduli lingkungan antara mahasiswa yang memperoleh matakuliah PKLH Plus, mahasiswa yang memperoleh matakuliah PKLH biasa, dan mahasiswa yang tidak memperoleh mata kuliah PKLH? 


\section{METODE}

Berdasarkan permasalahannya, penelitian ini merupakan penelitian komparatif, yakni membandingkan kecenderungan berperilaku (behavior intention) peduli lingkungan mahasiswa di berbagai program studi/ jurusan di lingkungan FISE UNY. Perbandi ngan perilaku dilakukan karena terdapat perbedaan dalam porsi pendidikan lingkungan antar kelompok mahasiswa (program studi). Dilihat dari unit analisisnya, penelitian ini termasuk dalam penelitian sampel, sehingga hasilnya dapat digunakan untuk melakukan generalisasi terhadap populasi. Penelitian ini dilaksanakan pada bulan April - Agustus 2009 dengan mengambil lokasi di Fakultas Ilmu Sosial dan Ekonomi UNY.

Populasi penelitian ini adalah seluruh mahasiswa S-1 FISE UNY. Menurut data di Sub bagian Akademik FISE UNY (2007), dari 10 program studi terdapat jumlah mahasiswa aktif dari angkatan 2001 sampai 2008 pada semester gasal 2007/2008 adalah 3742 orang. Untuk keperluan penelitian ini, mahasiswa yang dijadikan populasi adalah angka$\tan 2002$ sampai 2005. Alasannya adalah (1) untuk mahasiswa angkatan 2000 dan 2001 sebagian besar telah lulus dan sisanya sudah tidak aktif mengambil kuliah sehingga sulit ditemui; (2) mahasiswa angkatan 2007, belum menerima mata kuliah PKLH, baik pada mahasiswa yang pada kurikulumnya terdapat PKLH maupun mahasiswa Pendidikan Geografi yang memperoleh pendidikan lingkungan plus. Berdasarkan alasan-alasan tersebut, maka jumlah populasi penelitian ini ditentukan sebanyak 2507 mahasiswa.

Selanjutnya untuk keperluan pengambilan sampel, populasi tersebut diklasifikasikan menjadi tiga, yakni: a) Mahasiswa yang memperoleh mata kuliah pendidikan lingkungan plus (PKLH plus mata kuliah lingkungan lainnya). Mahasiswa yang termasuk dalam kelompok ini adalah mahasiswa Program Studi Pendidikan Geografi. Jumlah mahasiswa kelompok adalah 266 orang; b) Mahasiswa yang memperoleh mata kuliah pendidikan lingkungan (PKLH), di luar Program Studi Pendidikan Geografi, yakni mahasiswa Program Studi PKnH (219) mahasiswa), Pendidikan Ekonomi (273 mahasiswa), Pendidikan Sejarah (229 mahasiswa), dan Pendidikan Sosiologi (223 mahasiswa). Kelompok ini berjumlah 944 orang; c) Mahasiswa yang tidak memperoleh pendidikan lingkungan (PKLH).

Kelompok ini adalah mahasiswa Jurusan/ Program Studi Administrasi Perkantoran (231 mahasiswa), Program Studi Pendidikan Akuntansi (294 mahasiswa), Program Studi Akuntansi (243 mahasiswa), Program Studi Ilmu Sejarah (91 mahasiswa), dan Program Studi Manajemen (438 mahasiswa). Jumlah kelompok mahasiswa ini adalah 1297 mahasiswa.

Selanjutnya untuk efektivitas pengambilan data digunakan teknik pengambilan sampel. Sampel penelitian merupakan anggota populasi yang mewakili populasi mahasiswa dari jurusan/prodi yang memperoleh PKLH, mahasiswa yang memperoleh pendidikan lingkungan plus dan mahasiswa yang tidak memperoleh PKLH. Masing-masing diambil dari berbagai jurusan/program studi secara acak.

Untuk memperoleh sampel yang representatif maka perlu dilakukan langkah-langkah sebagai berikut.

Ada berbagai cara/rumus untuk menentukan jumlah sampel yang biasa digunakan untuk penelitian sosial, untuk penentuan jumlah sampel dalam penelitian ini menggunakan hasil perhitungan Krejcie dan Morgan (Huseini Usman dan Setiady Akbar, 2009:49) yang mendasarkan perhitungannya dengan rumus sebagai berikut:

$$
S=\frac{X^{2} N P(1-P)}{d^{2}(N-1)-X^{2} P(1-P)}
$$

Keterangan :

$\mathrm{S}=$ banyaknya anggota sampel

$\mathrm{N}=$ banyaknya anggota populasi

$\mathrm{P}=$ proporsi dalam populasi

$\mathrm{d}=$ derajat ketelitian $(=1,96)$

$\mathrm{X}^{2}=$ harga tabel chi square

Sebagaimana disebut di atas jumlah populasi dalam penelitian ini adalah 2705 maha- 
siswa, selanjutnya berdasar Formula di atas diperoleh sampel sebanyak 338 mahasiswa.

Teknik pengambilan sampel yang digunakan dalam penelitian ini adalah kombinasi proportional sampling dan systematic random sampling. Teknik pertama digunakan karena karakteristik populasi yang beragam untuk masing-masing program studi, sehingga dengan teknik ini sampelnya berimbang untuk masing-masing kelompok populasi nya. Penentuan proporsi sampel sebagaimana disajikan pada tabel 1 berikut ini.

Penentuan proporsi sampel terangkum pada tabel 1

Tabel 1. Kerangka Sampel Penelitian

\begin{tabular}{|c|c|c|c|c|}
\hline Kelompok Populasi & $\begin{array}{c}\text { Sub kelompok } \\
\text { sampel }\end{array}$ & $\begin{array}{c}\text { Proporsi sampel } \\
\text { (\%) }\end{array}$ & $\begin{array}{l}\text { Sampel/ } \\
\text { Kelompok }\end{array}$ & $\begin{array}{l}\text { Jumlah } \\
\text { sampel }\end{array}$ \\
\hline Mahasiswa PKLH Plus & P. Geografi & 10,61 & 36 & 36 \\
\hline \multirow[t]{4}{*}{ Mahasiswa PKLH Biasa } & PKN & 37,65 & 127 & 29 \\
\hline & P. Ekonomi & & & 37 \\
\hline & P. Sejarah & & & 31 \\
\hline & P.Sosiologi & & & 30 \\
\hline \multirow[t]{5}{*}{ Mahasiswa Non-PKLH } & Akuntasi & 51,74 & 175 & 33 \\
\hline & ADP & & & 31 \\
\hline & P.Akuntasi & & & 40 \\
\hline & I.Sejarah & & & 12 \\
\hline & Manajemen & & & 59 \\
\hline Jumlah & & 100,00 & 338 & 338 \\
\hline
\end{tabular}

Sumber: Hasil perhitungan

\section{Prosedur}

Mahasiswa FISE yang terdiri atas 10 program studi diklasifikasikan menjadi 3, yakni kelompok mahasiswa yang memperoleh pendidikan lingkungan dalam porsi yang lebih besar (Program Studi Pendidikan Geografi), mahasiswa program studi yang hanya memperoleh Mata Kuliah PKLH, dan mahasiswa dari program studi yang tidak memperoleh PKLH.

Data yang diukur dalam penelitian ini adalah skor perilaku mahasiswa terhadap lingkungan. Pengukuran sikap dalam penelitian ini adalah dengan menggunakan Mo del Feshbein Diperluas (Extended Feshbein Model) atau yang lebih dikenal dengan Theory of Reasoned Action (Fishbein dan Ajzen, 1975:61). Model ini pada prinsipnya meng- hitung Ab (Attitude toward behavior), yakni dengan menghitung keseluruhan atribut (multiatribut) yang berupa sikap terhadap objek dan keinginannya untuk bertindak, kemudian disertai dengan pengaruh kelompok reference (orang-orang di sekitar) dengan bobot tertentu. Model tersebut dapat diformulasikan sebagai berikut:

$\mathrm{BI} \approx(w 1 . A b)+(w 2 . S N)$

Keterangan:

$\mathrm{BI}=$ Behavior Intenstion

$w 1=$ bobot untuk $\mathrm{Ab}$

w2=bobot untuk SN

$\mathrm{Ab}=$ Sikap terhadap perilaku atas dasar keyakinan dirinya 
Prosedur analisisnya adalah sebagai berikut:

Menghitung Belief $(A b)$ terhadap perilaku tertentu, yakni keyakinan mengenai konsekuensi karena melakukan suatu tindakan. $A b$ dinyatakan dengan formula berikut:

$$
A b=\sum b_{i} x e_{i}
$$

Keterangan:

$\mathrm{Ab}=$ sikap terhadap perilaku

$\mathrm{Bi}=$ keyakinan konsumen terhadap konsekuensi i

$\mathrm{Ei}=$ evaluasi konsumen terhadap konsekuensi $i$

Sikap dalam penelitian ini diklasifikasikan menjadi 3, yakni baik, sedang, dan tidak baik. Klasifikasi tersebut didasarkan pada pada kemungkinan semua item dijawab de ngan skor maksimal dan minimal, selanjutkan dihitung dengan rumus tersebut, sehingga dapat diketahui skor terendah adalah 20 dan skor tertinggi 300.

Tabel 2. Klasifikasi Skor Sikap mahasiswa

\begin{tabular}{|c|c|c|}
\hline No & Kelas Sikap & Skor \\
\hline 1. & Baik & $>201$ \\
\hline 2. & Sedang & $111-200$ \\
\hline 3. & Tidak baik & $20-110$ \\
\hline
\end{tabular}

Sumber: hasil perhitungan

Menghitung Subjective Norm (SN)

$$
S N=\sum b_{i} x m_{i}
$$

bi =keyakinan terhadap pendapat kelompok referensi

$\mathrm{mi}=$ keinginan untuk menuruti pendapat kelompok referensi

Berdasarkan rumus tersebut, maka kemungkinan skor tertinggi SN adalah 160 dan skor terendah 10, maka SN dapat diklasifikasikan sebagaimana tabel 3 berikut.

Tabel 3. Klasifikasi Skor Norma Subjektif

\begin{tabular}{llr}
\hline No & \multicolumn{1}{c}{ Kelas Sikap } & \multicolumn{1}{c}{ Skor } \\
\hline 1. & Baik & $111-160$ \\
2. & Sedang & $61-110$ \\
3. & Tidak baik & $10-60$ \\
\hline
\end{tabular}

Menghitung bobot $w_{1}$ dan $w_{2}$, jumlah $w_{1}$ dan $w_{2}$ adalah $100 \%$. $w_{1}$ adalah bobot untuk
$A b$ dan $w_{2}$ adalah bobot untuk SN. Penghitu ngan bobot tersebut dapat dilakukan dengan 
dua cara, yakni: (1) berdasarkan data masa lalu yang selanjutnya dibuat model regresi; dan (2) membuat rata-rata $w_{1}$ dan $w_{2}$ yang didapat dari pendapat responden. Dalam penelitian ini cara yang digunakan adalah cara kedua.

Menghitung behavior intention (BI) atau tujuan berperilaku, yang merupakan perkalian $A b$ dengan $S N$, dengan memperhatikan bobot $w_{1}$ dan $w_{2}$ Formula untuk menghitung $B I$ adalah:

$B I=\left(w_{1} A_{b}\right)+\left(w_{2} S N\right)$.

$w_{1} A_{b}=$ proporsi sikap berdasarkan bobot

yang menentukan perilaku

$w_{2} S N=$ proporsi norma berdasarkan bobot yang menentukan perilaku

Selanjutnya untuk dapat melakukan analisis deskriptif, skor sikap diklasifikasikan menjadi 3 kelas. Klasifikasi skor tidak dapat dilakukan hanya dengan hanya menjum- lahkan skor jawaban tiap item pertanyaan, karena skor tiap jawaban tiap kelompok pertanyaan diolah dengan menggunakan rumus tertentu. Di samping itu, kedua variabel (sikap dan norma subjektif) memiliki bobot yang berbeda, sehingga jika skor responden pada kedua variabel sama besarnya, kemungkinan skor perilakunya berbeda, karena bobot kedua variabel tidak sama. Berdasarkan hasil perhitungan dengan menggunakan model perilaku menurut Fishbein Extended diketahui bahwa skor sikap adalah 40 - 160 dan skor norma subjektif adalah 20 - 80. Jika diasumsikan kedua variabel memiliki bobot (w1 dan w2) miniml dan maksimal, maka skor perilaku (Bi) terendah adalah 32 dan tertinggi adalah 130.

Selanjutnya berdasarkan kondisi kemungkinan data tersebut diperoleh, dapat dibuat 3 kelas perilaku (lihat Tabel 4) dengan lebar interval 40,

Tabel 4. Klasifikasi Skor Perilaku Peduli Lingkungan

\begin{tabular}{clc}
\hline No & Kelas & Interval \\
\hline 1. & Peduli & $>100$ \\
2. & Sedang & $66-99$ \\
3. & Tidak peduli & $32-65$ \\
\hline
\end{tabular}

Sumber: hasil perhitungan

Alasan pengunaan model tersebut adalah karena: (1) model ini dapat digunakan untuk membandingkan sikap antara orang yang mengalami langsung dan tidak langsung suatu kasus/kejadian. Sementara subjek yang diteliti dalam penelitian ini tidak hanya mahasiswa yang memperoleh mata kuliah pendidikan lingkungan. (2) Model Feshbein awal hanya mengukur sikap positif yang belum tentu diikuti dengan tindakan.

Rancangan langkah pengerjaan menghitung perilaku mahasiswa terhadap lingku ngan dalam penelitian ini adalah: (1) menghitung sikap $\left(\mathrm{A}_{i}\right)$ terhadap perilaku tertentu; (2) menghitung subjective norm (SN); (3) menghitung bobot $\mathrm{w}_{1}$ dan $\mathrm{w}_{2:}$ dan (4) Menghitung behavior $(B)$ atau sama dengan beha vior intention (BI), yang merupakan perkalian $\mathrm{A}_{b}$ dengan $S N$, dengan memperhatikan bobot $\mathrm{w}_{1}$ dan $\mathrm{w}_{2}$.

Teknik pengumpulan data penelitian ini adalah (1) angket yang bersifat tertutup, (2) Dokumentasi, digunakan untuk mengumpulkan data jumlah mahasiswa keseluruhan, jumlah mahasiswa tiap angkatan dan jumlah mahasiswa tiap jurusan.

Angket disusun dengan menggunakan Skala Likert. Contoh pertanyaan dalam angket yang terkait dengan keyakinan (belief):

"Apakah keberadaan ruang terbukar hijau di kota yang memiliki peran dalam mendukung kesegaran udara kota, adalah pen ting bagi saudara?" 
Dengan alternatif jawaban:

$\begin{array}{ccccc}5 & 4 & 3 & 2 & 1 \\ \text { SS/SP } & \text { S/P } & \text { N } & \text { TS/TP } & \text { STS/STP }\end{array}$

\author{
Keterangan: \\ SS $/$ SP = Sangat setuju/Sangat Penting \\ $\mathrm{S} / \mathrm{P} \quad=$ Setuju/Penting \\ $\mathrm{N} \quad=$ Netral \\ TS/TP = Tidak Setuju/Tidak Penting \\ STS/STP= Sangat Tidak Setuju/Sangat Tidak Penting
}

Alternatif jawaban "penting" digunakan khusus untuk menjawab/merespon pernyataan yang berisi komponen evaluasi

Dalam penelitian ini, hanya menggunakan 4 alternatif jawaban, yakni dengan meniadakan alternatif netral. Maksud ditiada kannya alternatif jawaban tersebut untuk menghindari kecenderungan responden yang mencari aman dengan memilih pernyataan netral. Dengan demikian, responden diharuskan memilih alternatif jawaban mo derat setuju/penting atau tidak setuju/tidak penting dan jawaban ekstrim sangat setuju/ sangat penting atau sangat tidak setuju/sa ngat tidak penting saja.

Uji validitas internal untuk keperluan vaiditas instrument yang digunakan adalah teknik analisis kesahihan butir (anabut) de ngan rumus korelasi Product Moment Pearson. Berdasarkan uji validitas pada taraf signifikansi 0,05 diketahui bahwa semua item memiliki koefisien korelasi yang signifikan, kecuali item soal nomor 37.

Uji reliabilitas internal dilakukan dengan uji coba dibelah dua menjadi skor awal dan skor akhir, yakni dengan membelah skor ins trumen nomor 1-30 dan nomor 31-60. Selanjutnya skor tersebut diuji dengan menggunakan teknik alpha, dengan taraf signifikansi 0,05. Hasil analisis data menunjukan bahwa koefisien alpha Cronbach's sebesar 0,952 . Korelasi antara belah awal dan belah akhir masing-masing 0,92 dan korelasi belah awal dan belah akhir 0,833., sehingga dapat dinyatakan bahwa instrumen tersebut reliabel.

\section{Teknik Analisis Data}

Teknik analisis yang digunakan untuk menguji menjawab permasalahan adalah (1) analisis deskriptif dilakukan dengan menggunakan tabel frekuensi, mean, median, dan modus. (2) Anova klasifikasi tunggal (Oneway Anova). Hasil uji Anava dinjutkan de ngan uji lanjut yang berupa post hoc test dan homogeneous subsets.

Hasil uji normalitas data sikap untuk ketiga kelompok mahasiswa adalah normal. Uji homoginitas varians, untuk mengetahui varians beberapa bagian sampel, yakni tingkat keseragaman variansi sampel-sampel yang diambil dari populasi yang sama. Uji homoginitas dilakukan dengan Uji-F.

Hasil pengujian homogenitas varians menunjukan bahwa koefisien Levene statistik sebesar 0,094 pada taraf signifikansi 0,910. Karena nilai probabilitas $>0,05$, dapat diambil keputusan bahwa ketiga varians tidak sama (homogin). Berdasarkan fakta tersebut maka data dapat dilakukan uji lanjut terhadap data tersebut dengan teknik analisis anava.

\section{hasil dan pembahasan}

Peranan Sikap dan Norma Subjektif dalam Pembentukan Perilaku

Data dalam penelitian berupa skor sikap, 
skor norma subjektif, skor bobot pengaruh kelompok referensi (dosen dan teman), dan skor maksud/tujuan berperilaku (behavior intention) mahasiswa dari 3 kelompok jurusan di FISE UNY. Data unsur-unsur behavior intention ketiga kelompok mahasiswa terhadap lingkungan yang telah diolah dengan metode statistik deskriptif dapat diuraikan sebagai berikut:

\section{Sikap}

Data sikap terdiri dari data keyakinan dan data evaluasi mahasiswa terhadap suatu atribut tertentu. Data keyakinan dan evaluasi tersusun atas sejumlah atribut, masingmasing atribut memiliki skor rata-rata. Skor sikap merupakan hasil perkalian antara skor keyakinan dan evaluasi terhadap atribut $i$. Adapun atribut keyakinan dan evaluasi mencakup 6 komponen yakni, keyakinan dan evaluasi mahasiswa terhadap tidak benarnya mentalitas frontier, keyakinan dan evaluasi mahasiswa terhadap lingkungan hidup seba gai syarat mutlak kehidupan, keyakinan dan evaluasi mahasiswa bahwa lingkungan mempunyai keterbatasan, keyakinan dan evaluasi mahasiswa bahwa fungsi lingku ngan harus dilestarikan dan keyakinan dan evaluasi mahasiswa terhadap kekeliruan pandangan pribadi. Besarnya skor komponen-komponen/atribut penyusun sikap berada pada interval 1-4, (skor 1 menunjukan bahwa pada atribut tersebut mempunyai kadar tidak peduli dan skor 4 menunjukan kadar peduli lingkungan). Skor tersebut merupakan variabel kontinum.

Secara umum dapat diketahui bahwa skor atribut dari komponen keyakinan dan evaluasi berada pada tingkat yang rendah sampai sedanng. Hal ini ditunjukkan oleh skor yang tidak ada satupun yang mencapai tiga. Hal yang cukup memprihatinkan adalah pada atribut keyakinan tidak benarnya mentalitas frontier, ternyata di semua kelompok mahasiswa tidak ada yang memiliki skor sampai dua. Atribut komponen evaluasi yang mencapai skor dua hanya di kelompok PKLH Plus pada komponen nomor dua, kelompok mahasiswa PKLH Biasa pada komponen nomor dua dan tiga, dan pada kelompok mahasiswa non PKLH tidak ada.

Untuk mengetahui peranan sikap dalam pembentukan kecenderungan berperilaku (Bi), maka perlu diketahui dimensi dan atribut penyusunnya. Tabel 5 berikut ini menggambarkan secara kuantitatif (skor rata-rata) dua komponen penyusun sikap.

Tabel 5. Skor Rata-rata Belief dan Evaluasi Tiga Kelompok Mahasiswa

\begin{tabular}{lcccccc}
\hline & \multicolumn{5}{c}{ B dan E pada Tiap Kelompok Mahasiswa } \\
\cline { 2 - 7 } \multicolumn{1}{c}{ Atribut } & \multicolumn{2}{c}{ PKLH Plus } & \multicolumn{2}{c}{ PKLH Biasa } & \multicolumn{2}{c}{ Non PKLH } \\
\cline { 2 - 7 } & $\mathrm{B}$ & $\mathrm{E}$ & $\mathrm{B}$ & $\mathrm{E}$ & $\mathrm{B}$ & $\mathrm{E}$ \\
\hline $\begin{array}{l}\text { Tidak benarnya mentalitas } \\
\text { frontier }\end{array}$ & 1,98 & 1,75 & 1,84 & 1,78 & 1,67 & 1,78 \\
$\begin{array}{l}\text { Lingkungan hidup sebagai } \\
\text { syarat mutlak kehidupan }\end{array}$ & 2,28 & 2,10 & 2,09 & 2,04 & 1,91 & 1,92 \\
$\begin{array}{l}\text { Lingkungan mempunyai } \\
\text { keterbatasan }\end{array}$ & 2,29 & 1,85 & 2,12 & 1,95 & 1,92 & 1,80 \\
$\begin{array}{l}\text { Fungsi lingkungan harus } \\
\text { dilestarikan }\end{array}$ & 1,96 & 1,89 & 1,80 & 2,09 & 1,79 & 1,97 \\
$\begin{array}{l}\text { Untuk hidup sehat perlu } \\
\text { lingkungan sehat }\end{array}$ & 2,36 & 1,96 & 2,14 & 1,95 & 2,05 & 1,82 \\
\begin{tabular}{l} 
Kekeliruan pandangan pribadi \\
\hline
\end{tabular} & 2,04 & 1,88 & 1,92 & 1,95 & 1,86 & 1,84 \\
\hline
\end{tabular}

Keterangan: $B=$ Bilief $\quad E=E v a l u a s i$

Sumber : Hasil pengolahan data primer 


\section{Sikap mahasiswa kelompok PKLH Plus}

Sikap merupakan hasil keyakinan yang dimiliki oleh seseorang dan evaluasi sese orang terhadap konsekuensi dari dilakukannya suatu atribut. Berdasarkan hasil perhitungan terhadap atribut sikap mahasiswa PKLH Plus terhadap lingkungan diketahui bahwa hampir semua atribut memiliki pe ran dalam membentuk keyakinan, dimana keyakinan itu sendiri mempengaruhi sikap. Dari 6 kelompok atribut (dimensi) yang pa ling tinggi porsinya adalah keyakinan bahwa hidup sehat perlu lingkungan sehat dengan skor rata-rata 2,36. Kelompok atribut lainnya yang memiliki peranan besar adalah keyakinan bahwa lingkungan memiliki keterbatasan dan keyakinan terhadap lingkungan hidup sebagai syarat mutlak kehidupan masing-masing dengan skor rata-rata 2,29 dan 2,28 . Dengan kata lain, kelompok mahasiswa ini mempunyai keyakinan yang baik.

Evaluasi mahasiswa kelompok ini terhadap konsekuensi dari dilakukannya atribut tertentu dalam membentuk sikap terhadap lingkungan menunjukan bahwa dimensi yang paling berperan dalam pembentukan sikap adalah evaluasi terhadap lingkungan hidup sebagai syarat mutlak kehidupan dan kelompok atribut yang paling rendah pera nannya adalah evaluasi terhadap tidak benar nya mentalitas frontier dengan skor rata-rata 1,72 .

Rata-rata skor sikap kelompok mahasiswa PKLH Plus adalah 80,81, skor yang pa ling rendah adalah 41 dan yang paling tinggi adalah 115. Berdasarkan klasifikasi sikap yang dibagi menjadi peduli, kurang peduli, tidak peduli, maka sikap kelompok mahasiswa ini termasuk dalam kelas sikap peduli.

Sikap Mahasiswa kelompok PKLH Biasa. Keyakinan bahwa hidup sehat perlu lingkungan sehat dan keyakinan bahwa lingku ngan hidup sebagai syarat mutlak kehidupan merupakan kelompok atribut yang diyakini oleh kelompok mahasiswa ini masing-masing dengan skor rata-rata 2,28 dan 2,19. Se- mentara kelompok atribut yang tidak begitu diyakini oleh kelompok mahasiswa ini adalah keyakinan terhadap tidak benarnya mentalitas frontier yakni dengan skor rata-rata 1,84.

Dari hasil perhitungan diketahui bahwa kelompok atribut yang memiliki konseku ensi terbesar dalam membentuk sikap mahasiswa PKLH Biasa adalah evaluasi terhadap pentingnya kesehatan lingkungan yakni dengan skor rata-rata 2,14. Dimensi lainnya yang memiliki konsekuensi yang hampir sama adalah evaluasi terhadap lingkungan hidup sebagai syarat mutlak kehidupan dengan skor rata-rata 2,06. Dimensi yang paling yang dianggap memiliki konsekuensi paling kecil terhadap pilihan sikap mahasiswa pada lingkungan adalah evaluasi terhadap tidak benarnya mentalitas frontier.

\section{Sikap Mahasiswa kelompok Non PKLH}

Keyakinan bahwa untuk hidup sehat perlu lingkungan sehat adalah dimensi yang diyakini memiliki peranan terbesar dalam membentuk sikap mahasiswa Non PKLH yakni dengan skor 2,08. Disamping itu terdapat 2 dimensi lain yang memiliki peranan besar dalam membentuk keyakinan yakni keyakinan terhadap lingkungan hidup seba gai syarat mutlak kehidupan dan keyakinan bahwa lingkungan mempunyai keterbatasan masing-masing dengan skor rata-rata 1,95. Dimensi yang paling kecil adalah keyakinan terhadap tidak benarnya mentalitas frontier dengan skor rata-rata 1,63.

\section{Norma Subjektif}

Norma subjektif mencakup keyakinan terhadap pendapat kelompok referensi dan motivasi untuk menuruti pendapat tersebut. Berdasarkan hasil analisis data diperoleh informasi mengenai skor atribut keyakinan terhadap pendapat kelompok referensi dan motovasi untuk menuruti pendapat tersebut sebagaimana tersaji pada tabel 3 berikut. 
Tabel 3.

Skor Rata-rata Atribut Keyakinan terhadap Pendapat Kelompok Referensi dan Kemauan untuk menurutinya

\begin{tabular}{ccccc}
\hline \multirow{2}{*}{ Kelompok Mahasiswa } & \multicolumn{4}{c}{ Delompok Referensi } \\
\cline { 2 - 5 } & bi & Mi & Ebi & mi \\
\cline { 2 - 5 } & 2,03 & 1,98 & 1,61 & 1,60 \\
PKLH Plus & 2,00 & 1,88 & 1,65 & 1,69 \\
PKLH Biasa & 1,83 & 1,91 & 1,66 & 1,38 \\
Non-PKLH & & & &
\end{tabular}

Keterangan: bi = keyakinan pada pendapat kelompok referensi

$\mathrm{mi}=$ dorongan untuk menuruti pendapat kelompok referensi

\section{Norma Subjektif Mahasiswa PKLH Plus}

Berdasarkan skor total norma subjektif mahasiswa ini, skor tertinggi adalah 80 dan terendah 12 . Skor rata-ratanya adalah 34,53 (kategori jelek).

\section{Pengaruh Dosen dan teman terhadap keyakinan}

Dosen merupakan bagian dari kelompok yang pendapatnya berpengaruh pada keyakinan dan kemauan untuk menuruti dalam berperilaku. Dilihat dari rata-rata skor keyakinan mahasiswa terhadap pendapat dosen dan teman, keduanya memiliki skor yang hampir sama, masing-masing 2,03 dan 1,61. Berdasarkan kenyataan angka tersebut menunjukan bahwa pembelajaran lingku ngan kurang memiliki peranan yang besar dalam membentuk keyakinan mahasiswa karena skor rata-rata keyakinan kelompok mahasiswa PKLH Plus sedikit lebih tinggi daripada ke pendapat dosen.

Motivasi untuk menuruti pendapat kelompok referensi mahasiswa PKLH Plus

Pendapat kelompok referensi yang cenderung untuk dituruti oleh kelompok mahasiswa ini adalah pendapat dosen, yakni dengan skor rata-rata 1,98 , sementara skor rata-rata untuk menuruti pendapat teman sebesar 1,61. Dari fakta ini tampak keselarasan antara keyakinan dengan dorongan un- tuk menurutinya. Pada tabel 6 tampak ratarata skor atribut keyakinan dan dorongan menuruti pendapat sama-sama tinggi. Disatu sisi kelompok mahasiswa ini lebih meyakini pendapat teman tetapi dalam hal motivasi untuk menuruti lebih cenderung kepada pendapat dosen. Kenyataan ini terjadi karena mahasiswa menganggap pendapat dosen lebih valid karena berdasarkan literatur ilmiah, sementara pendapat temannya memang lebih mempengaruhi keyakinan, bukan karena validitas pendapat tetapi karena pengaruh kedekatan dengan teman sebaya.

\section{Norma Subjektif Mahasiswa PKLH Biasa}

Berdasarkan skor total norma subjektif mahasiswa ini, skor tertinggi adalah 90 dan terendah 12 . Skor rata-ratanya adalah 34,48 (tidak baik).

\section{Pengaruh Dosen dan teman terhadap keyakinan}

Fenomena tentang pengaruh kelompok referensi pada kelompok mahasiswa PKLH Biasa terhadap keyakinan sama dengan yang terjadi pada kelompok mahasiswa PKLH Plus, yakni mahasiswa lebih yakin pada pendapat teman, tetapi lebih besar motivasinya untuk menuruti pendapat dosen. Skor rata-rata keyakinan pada pendapat dosen adalah 2,00 dan skor rata-rata keyakinan pada pendapat teman 1,65. Motivasi untuk menuruti kelom- 
pok mahasiswa PKLH Biasa

Motivasi untuk menuruti pendapat kelompok referensi mahasiswa PKLH Biasa.

Motivasi untuk menuruti pendapat kelompok referensi pada mahasiswa kelompok ini lebih tinggi terhadap dosen daripada menuruti pendapat teman. Hal ini dapat dilihat dari skor rata-rata motivasi untuk menuruti pendapat dosen adalah 1,88 dan skor rata-rata untuk menuruti pendapat teman sebesar 1,69. Fakta bahwa mahasiswa lebih mempercayai dosen menjadi posisi strategis bagi pendidikan dalam rangka membentuk perilaku peduli lingkungan.

\section{Norma Subjektif Mahasiswa Non PKLH}

\section{Pengaruh Dosen dan teman terhadap keyakinan}

Pengaruh pendapat kelompok referensi terhadap keyakinan mahasiswa kelompok Non PKLH berimbang dalam arti bahwa antara pendapat dosen dan mahasiswa memiliki skor yang sama dalam mempengaruhi keyakinan kelompok mahasiswa ini. Skor rata-rata keyakinan pada pendapat dosen dan mahasiswa masing-masing 1,83 dan 1,66.

\section{Motivasi untuk menuruti pendapat ke- lompok referensi}

Motivasi untuk menuruti pendapat kelompok referensi pada mahasiswa Non PKLH bersesuain dengan bobot keyakinannya. Motivasi untuk menuruti pendapat dosen memiliki skor 1,91 dan skor rata-rata motivasi untuk menuruti pendapat teman sebesar 1,38. Rata-rata skor ini menunjukkan bahwa kelompok mahasiswa ini memiliki motivasi yang rendah untuk menuruti pendapat keduanya, baik pendapat dosen maupun temannya, meskipun skor untuk menuruti pendapat dosen lebih tinggi. Hal ini wajar mengingat bahwa dosen yang diposisikan sebagai kelompok referensi mahasiswa tersebut bukan dosen PKLH.

\section{Bobot $w$}

Bobot untuk sikap $A b$ dinamakan $w_{1}$ dan bobot norma subjektif dinamakan $w_{2}$. Jumlah keduanya adalah 100\%. Bobot ini menunjukan aspek mana yang paling menentukan terhadap seseorang dalam berperilaku yakni antara mengikuti sikap dirinya dan mengikuti pendapat kelompok referensi (dosen dan teman).

\section{Proporsi bobot $w$ kelompok mahasiswa PKLH Plus}

Secara keseluruhan rata-rata kelompok mahasiswa ini dalam berperilaku lebih ditentukan oleh sikap dia sendiri daripada mengikuti pendapat kelompok referensi. Hal ini dapat dilihat dari bobot $w_{1}$ dan $w_{2}$ masingmasing $73,83 \%$ dan $26,17 \%$. Persentase pertama menunjukan bahwa sikap mahasiswa dalam berperilaku memiliki porsi sebanyak $73,83 \%$ dan porsi pendapat kelompok refe rensi $26,17 \%$.

\section{Proporsi bobot $w$ kelompok mahasiswa PKLH Biasa}

Sebagaimana kelompok mahasiswa PKLH Plus ternyata perilaku terhadap lingkungan lebih banyak dipengaruhi oleh sikap mahasiswa sendiri daripada menuruti pendapat kelompok referensi. Proporsi sikap kelompok mahasiswa ini dalam membentuk $\mathrm{Bi}$ adalah $70 \%$ dan proporsi mengikuti pendapat kelompok dosen dan teman adalah $30 \%$.

\section{Proporsi bobot $w$ kelompok mahasiswa Non PKLH}

Perilaku kelompok mahasiswa terhadap lingkungan ditentukan oleh sikapnya sendiri daripada mengikuti pendapat kelompok refe rensi. Hal ini dapat dilihat dari bobot $w_{1}$ dan $w_{2}$ masing-masing $67 \%$ dan $33 \%$. Persentase pertama menunjukan bahwa sikap mahasiswa dalam berperilaku memiliki porsi sebanyak $67 \%$ dan porsi pendapat kelompok referensi 33\%. Dibandingkan dengan kelompok mahasiswa Plus, kelompok mahasiswa ini lebih menuruti kelompok referensi, yakni dengan selisih $3 \%$.

Berdasarkan fakta tentang proporsi sikap dan kelompok referensi diketahui bahwa perilaku ketiga kelompok mahasiswa lebih banyak dipengaruhi oleh sikap mereka sen 
diri daripada menuruti pendapat kelompok referensi. Hal ini menunjukan bahwa pendidikan lingkungan belum efektif dalam mempengaruhi perilaku mahasiswa untuk peduli dengan lingkungan.

\section{Perilaku Peduli Lingkungan Mahasiswa FISE UNY}

Perilaku menurut Model Sikap Fishbein terbentuk oleh sikap seseorang sendiri dan norma subjektif (pengaruh keyakinan dan motivasi untuk menuruti kelompok referensi atau pendapat orang-orang yang berada di sekitarnya, yang dalam penelitian ini adalah dosen dan mahasiswa). Berdasarkan model tersebut, maka pembahasan hasil penelitian tentang perilaku lingkungan mahasiswa FISE UNY berikut difokuskan pada kedua hal tersebut.

Perilaku (Behavior) menurut Extended Fishbein Model diekuivalensikan dengan behavior intention (Bi) berarti tujuan untuk berperilaku yang bisa dianggap sama de ngan perilaku itu sendiri, atau dalam kasus ini jika mahasiswa sudah mempunyai intention (maksud) untuk berinteraksi dengan lingkungan melalui perilaku tertentu maka mereka akan berperilaku demikian (jadi berinteraksi dengan intensinya), misalnya jika mahasiswa bermaksud untuk menanam pohon maka mereka akan berperilaku menanam pohon. Inilah bedanya antara model sikap Fishbein diperluas dengan model sikap Fishbein pertama, yang hanya mengukur sikap tanpa dikaitkan kemungkinan berperilaku atau tidak, sehingga kurang dapat diramalkan secara lebih meyakinkan. Untuk mengtahui kelas perilaku ini, perhatikan tabel 3 .

\section{Perilaku peduli lingkungan kelompok mahasiswa PKLHP lus}

Rata-rata skor perilaku mahasiswa kelompok PKLH Plus adalah 69,5. Sementara skor terendah adalah 36 dan tertinggi 100. Jika diklasifikasikan ke dalam tiga kelas perilaku maka mahasiswa kelompok ini termasuk dalam kategori perilaku sedang (di antara peduli dan tidak peduli). Meskipun demikian perilaku ini hanya berdasarkan in- tention yang boleh jadi mereka mempraktikannya lebih dari sekedar skor kelas perilaku atau bahkan mungkin kurang peduli.

\section{Perilaku peduli lingkungan kelompok mahasiswa PKLH Biasa}

Perilaku peduli lingkungan kelompok mahasiswa ini memiliki skor terendah 29 dan skor tertinggi 100, dengan skor rata-rata 65,07 . Meskipun skor terendah dan tertinggi serta rata-rata kelompok mahasiswa ini lebih rendah daripada kelompok mahasiswa PKLH Plus, tetapi dalam klasifikasi perilaku dalam penelitian ini tergolong dalam kelas yang sama dengan kelas perilaku kelompok mahasiswa PKLH Plus yakni kelas sedang (61 - 100). Fakta ini menunjukkan bahwa pemberian mata kuliah pendidikan lingkungan ini memiliki peran yang berarti, terbukti perilaku kelompok mahasiswa ini meski dengan skor yang berbeda tetapi berada di kelas yang sama dengan kelompok mahasiswa PKLH Plus.

\section{Perilaku peduli lingkungan kelompok mahasiswa Non-PKLH}

Perilaku peduli lingkungan kelompok mahasiswa ini memiliki skor yang paling rendah Siantar ketiga kelompok. Skor yang diperoleh adalah terendah 21 dan skor tertinggi 100, dengan skor rata-rata 59,01. Dibandingkan dengan kedua kelompok mahasiswa lain, rata-rata skor perilaku mahasiswa kelompok ini tergolong paling rendah. Berdasarkan klasifikasi perilaku kelompok mahasiswa ini tergolong dalam kelas tidak peduli terhadap lingkungan. Kenyataan ini masuk akal, karena kelompok ini tidak memperoleh mata kuliah pendidikan kependudukan dan lingkungan hidup.

\section{Perbedaan Perilaku Mahasiswa terhadap Lingkungan pada 3 kelompok Mahasiswa}

\section{Hasil Pengujian Hipotesis}

Hasil pengujian dengan Anava terhadap data Bi (behavior intention) dari tiga kelompok mahasiswa FISE UNY yang memperoleh pendidikan lingkungan yang berbeda diperoleh informasi bahwa koefisien $\mathrm{F}$ sebe- 
sar 6,948 dengan probabilitas signifikansi 0,01 . Probablitias koefisien signifikansi yang ditetapkan untuk dinyatakan suatu hipotesis diterima untuk keperluan pengujian ini adalah $<0,05$ atau sebagai syarat untuk dinyatakan sebagai fakta terdapat perbedaan nyata. Dengan demikian hipotesis nihil yang menyatakan bahwa tidak terdapat perbedaan yang signifikan antara Bi kelompok mahasiswa PKLH Plus, PKLH Biasa dan Non PKLH ditolak, karena koefisien signifikansi lebih kecil dari 0,05 (lihat Tabel 4). Berdasarkan fakta tersebut maka hipotesis alternatif yang menyatakan bahwa terdapat perbedaan yang signifikan antara Bi dari kelompok mahasiswa PKLH Plus, PKLH Biasa dan Non PKLH diterima. Artinya, perilaku peduli lingkungan yang dimiliki oleh masing-masing kelompok mahasiswa itu berbeda secara nyata.

Tabel 4. Hasil Analisis Anava Bi

\begin{tabular}{lrrrrr} 
& Sum of Squares & df & Mean Square & F & Sig. \\
\hline Between Groups & 4730.131 & 2 & 2365.1 & 6.948 & .001 \\
Within Groups & 114025.4 & 335 & 340.4 & & \\
Total & 118755.5 & 337 & & & \\
\hline
\end{tabular}

Sumber: hasil perhitungan dengan SPSS

\section{Hasil Uji lanjut (post hoc test)}

Berdasarkan fakta bahwa hasil pengujian rata-rata $B i$ pada tiga kelompok menunjukkan perbedaan yang signifikan, maka langkah berikutnya adalah melakukan uji lanjut anava (post hoc tes) yakni dengan uji Tukey dan Scheffe. Berdasarkan uji tersebut diperoleh:

Perbedaan rata-rata (mean difference) $\mathrm{Bi}$ kelompok mahasiswa PKLH Plus dengan kelompok mahasiswa PKLH biasa adalah 4,429 pada signifikansi 0,412 (menurut Tukey) dan 0,446 (menurut Scheffe). Dengan demikian karena probabilitas koefisien signifikansi de ngan kedua uji tersebut $>0,05$ maka dapat di nyatakan bahwa Bi antar kedua kelompok tersebut tidak signifikan.

Perbedaan rata-rata (mean difference) $\mathrm{Bi}$ kelompok mahasiswa PKLH Plus dengan Non PKLH adalah 10,489 pada signifikansi 0,06 (menurut Tukey) dan 0,009 (menurut Scheffe). Berdasarkan koefisien signifikansi tersebut yang memiliki nilai $<0,05$ maka dapat dinyatakan bahwa terdapat perbedaan yang signifikan antara Bi kelompok mahasiswa PKLH Plus dengan Non PKLH.

Perbedaan rata-rata (mean difference) Bi kelompok mahasiswa PKLH Biasa dengan kelompok mahasiswa Non PKLH adalah
6,059 pada level signifikansi 0,014 (menurut Tukey) dan 0,20 (menurut Scheffe). Ini menunjukkan bahwa antara kedua kelompok mahasiswa tersebut memiliki perbedaan $\mathrm{Bi}$ yang signifikan. Hal ini menunjukkan keberartian mata kuliah PKLH bagi mahasiswa.

\section{Uji Homogenous Subsets}

Setelah diketahui perbedaan Bi antar kelompok selanjutnya dilakukan uji kesamaan (homogeneous subsets). Berbeda dengan Uji Tukey dan Schefe yang digunakan untuk menguji kelompok mana saja yang berbeda, maka uji homogenous digunakan untuk mencari kelompok mana saja yang memiliki kesamaan. Uji ini dilakukan karena beberapa set data yang diuji secara bersama-sama dengan anava de ngan hasil berbeda secara signifikan, tetapi bila diuji per pasangan (antar subset) dapat saja terjadi persamaan (homogin).

Berdasarkan Uji homogenous dengan nilai alpha $=0,05$ diperoleh fenomena bahwa:

Rata-rata skor Bi kelompok mahasiswa PKLH Plus memiliki kesamaan dengan ratarata skor behavior intention kelompok mahasiswa PKLH Biasa, tetapi tidak memiliki kesamaan dengan kelompok mahasiswa Non PKLH. Hal ini dapat dilihat pada kolom 
subset 2, baik pada hasil Uji Tukey maupun Scheffe. Jika diuji secara bersama-sama ketiganya memiliki perbedaan nyata, tetapi jika dikomparasikan per bagian secara berpasangan, ternyata dapat terjadi kesamaan.

Rata-rata skor $B i$ kelompok mahasiswa
PKLH Biasa memiliki kesamaan dengan ratarata skor $B i$ kelompok mahasiswa Non PKLH. Hal ini dapat dilihat bahwa rata-rata keduanya berada di subset 1 , baik pada hasil Uji Tukey maupun Scheffe.

Tabel 5. Hasil Uji Homogenous Subset BI

\begin{tabular}{|c|c|c|c|c|}
\hline & Pend Lino & $\mathrm{N}$ & Subset for alpha $=0.05$ & \\
\hline & rend_Ling & IN & 1 & 2 \\
\hline \multirow[b]{2}{*}{ Tukey } & BI_PKLHNon & 175 & 59.01 & \\
\hline & BI_PKLH_Bs & 127 & 65.07 & 65.07 \\
\hline \multirow{2}{*}{$\mathrm{HSD}^{\mathrm{a}, \mathrm{b}}$} & BI_PKLHPlus & 36 & & 69.50 \\
\hline & Sig. & & .119 & .319 \\
\hline \multirow{4}{*}{ Scheffe $^{a, b}$} & BI_PKLHNon & 175 & 59.01 & \\
\hline & BI_PKLH_Bs & 127 & 65.07 & 65.07 \\
\hline & BI_PKLHPlus & 36 & & 69.50 \\
\hline & Sig. & & .143 & .353 \\
\hline
\end{tabular}

Means for groups in homogeneous subsets are displayed

a. Uses Harmonic Mean Sample Size = 72,523

$b$. The group sizes are unequal. The harmonic mean of the group sizes is used.

Type I error levels are not guaranteed.

\section{SIMPULAN}

Berdasarkan pembahasan yang diuraikan pada bab terdahulu dapat ditarik bebe rapa simpulan sebagai berikut:

Peranan sikap dan norma subjektif dalam membentuk perilaku mahasiswa pada setiap individu berbeda-beda, termasuk berbeda pada kelompok mahasiswa. Peran sikap dan norma subjektif dalam membentuk perilaku pada mahasiswa PKLH Plus adalah bobot sikap 74,25\% dan SN 25,75\%. Peran sikap dan norma subjektif pada kelompok mahasiswa PKLH Biasa masing-masing adalah 70\% dan $30 \%$, sementara bobot pada kelompok mahasiswa Non PKLH perannya ditunjukkan dengan bobot masing-masing 69\% dan 31\%. Dari ketiga kelompok mahasiswa tersebut ternyata proporsi atribut sikap lebih menentukan dalam pembentukan perilaku mahasiswa terhadap lingkungan.
Kelompok mahasiswa PKLH Plus dan PKLH Biasa memiliki perilaku peduli lingkungan pada tingkat sedang, dan kelompok mahasiswa non PKLH memiliki perilaku tidak peduli terhadap lingkungan. Perilaku mahasiswa terhadap lingkungan dari ketiga kelompok mahasiswa menunjukkan perbedaan yang signifikan. Berdasarkan uji lanjut (post hoc test), ternyata perilaku mahasiswa PKLH Plus dan PKLH Biasa tidak berbeda nyata, tetapi berbeda nyata dengan kelompok mahasiswa Non PKLH.

Berdasarkan temuan hasil penelitian ini, maka dapat disampaikan beberapa saran sebagai berikut.

Penguatan peran norma subjektif melalui peran strategis dosen dalam menanamkan perilaku positif terhadap lingkungan perlu terus dilakukan. Peran unsur sikap yang besar dalam pembentukan perilaku dapat tidak menguntungkan jika keyakinan dan evaluasi 
terhadap atribut tidak didasari pengetahuan yang cukup.

Pendidikan lingkungan perlu diberikan baik secara monolitik maupun secara terintegrasi pada semua jurusan di lingkungan FISE UNY

Perlu ada dukungan pimpinan lembaga pendidikan dalam bentuk kebijakan kurikulum, yakni dengan memasukkan Mata kuliah Pendidikan Lingkungan atau PKLH sebagai matakuliah wajib yang semula sebagai mata kuliah MPK yang seringkali tidak dipilih.

\section{UCAPAN TERIMA KASIH}

Kami mengucapkan terimakasih kepada :

Dekan FIS UNY, Prof. Dr. Ajat Sudrajat, M.Ag. yang telah memberikan fasilitas berupa ijin pelaksanaan penelitian.

Bapak/ibu dosen Jurusan Pendidikan Geografi, FIS, UNY yang telah memberikan bantuan moral serta masukan untuk kebaikan penelitian ini.

\section{DAFTAR PUSTAKA}

Aris, Muh Marfai. 2005. Moralitas Lingkungan Refleksi Kritis Atas Krisis Lingkungan Berkelanjutan. Yogyakarta: Wahana Hijau.

Chiras, Daniel D. 1991. Environmental Science: Action For A Sustaibale Future. Third Edition. Redwood City, California: The Benjamin/Cummings Publishing Company, Inc.
Fishbein, M., and I. Ajzen. 1975. Belief, Attitude, Intention, and behavior: an introduction to theory and reseearch. California: Addison-Wesley Publishing Company.

Hadi, Bambang Syaeful. 2008. Model Pembinaan Budaya Kampus Yang Peduli Lingkungan Di Fakultas Ilmu Sosial UNY. Jurnal Informasi Vol. 1, Th XXXIII, 355-470.

Hadi, Bambang Syaeful. 2009. Tanggapan Dosen Terhadap Pembelajaran Aspek Lingkungan Dalam Konteks Implementasi Kurikulum 2002 Di Fakultas Ilmu Sosial dan Ekonomi UNY. Jurnal Informasi Vol. 1 Th. XXXIV, 36-49.

MPBI. 2010. Kerusakan Lingkungan, Risiko Bencana Meningkat. Terdapat Di http:// www.mpbi.org/content/kerusakan-lingkungan-risiko-bencana-meningkat. Diakses pada tanggal 13 April 2010.

Reimer, Joseph, Diana Pritchaed Politto., and Richard H. Hers. 1983. Promoting Moral Growth From Piaget To Kohlberg. Second Edition. New York: Longman.

Sutrisnowati, Sri Agustin, dan Bambang Syaeful Hadi. 2005. Upaya Penanaman Kesadaran Lingkungan Dalam Konteks Implementasi Kurikulum 2002. Humanika Vol 5 Nomor 1, 45-51.

Undang-Undang Republik Indonesia Nomor 22, Tahun 1999 tentang Pemerintahan Daerah.

Usman, Husaini, dan Purnomo Setiadi Akbar. 2009. Metodologi Penelitian Sosial. Jakarta: Bumi Aksara.

Wardhana, Wisnu Arya. 2003. Dampak Pencemaran Lingkungan. Yogyakarta: Andi . 